\title{
VPLIV TURIZMA NA ZNAČILNOSTI CESTNEGA PROMETA V KOPRSKEM PRIMORJU
}

\author{
dr. Dejan Cigale \\ Oddelek za geografijo, Filozofska fakulteta Univerze v Ljubljani \\ Aškerčeva 2, SI-I000 Ljubljana \\ e-mail: dejan.cigale@ff.uni-lj.si \\ Izvirni znanstveni članek \\ COBISS 1.01 \\ DOI: $10.4312 /$ dela.39.2.27-47
}

\section{Izvleček}

Koprsko primorje je najbolj obiskano turistično območje v Sloveniji. Velik turistični obisk vpliva tudi na značilnosti prometa na tem območju. Analiza podatkov o dnevnem številu vozil za števna mesta prometa na tem območju je pokazala, da so spremembe v obsegu prometa $\mathrm{v}$ veliki meri povezane $\mathrm{z}$ razpoložljivostjo prostega časa in vremenom. Kljub temu so glede intenzivnosti in opaznosti tovrstnih vplivov znotraj območja precejšnje razlike, saj se na njem prepletajo vplivi turizma, drugih gospodarskih dejavnosti in lokalnega prebivalstva.

Ključne besede: promet, turizem, prosti čas, Koprsko primorje, vreme, število vozil

\section{INFLUENCE OF TOURISM ON THE CHARACTERISTICS OF ROAD TRAFFIC IN KOPRSKO PRIMORJE}

\begin{abstract}
Koprsko primorje (Koper Littoral) is the most visited tourist area in Slovenia. Huge number of tourist visits influences also the characteristics of traffic in the area. Analysis of data on daily number of vehicles for road traffic count points in this area has shown that changes in traffic volume are, to a large extent, related to the availability of free time and the weather. Despite this, there are considerable differences within the region in regard to intensity of these influences, what is the result of a combination of the influences of tourism, other economic activities and local population.
\end{abstract}

Key words: traffic, tourism, leisure, Koper Littoral, weather, number of vehicles 


\section{UVOD}

Turizem kot pojav, ki vključuje zapuščanje kraja stalnega bivališča oziroma 'običajnega okolja', je nujno povezan s prometom. Prometna dostopnost je predpogoj, da sploh pride do razvoja turizma. Pri tem promet ne predstavlja zgolj sredstva za dosego želenega cilja oziroma turističnega območja, ampak je lahko tudi del turističnega doživetja (npr. Hallo, Manning, 2009).

Pokrajinski učinki prometa in turizma dobivajo zaradi njune velike prostorske razširjenosti tudi širši regionalni značaj (Špes, 2009, str. 9). Obe dejavnosti kot medsebojno tesno povezana in prepletena pojava sta bili doslej že večkrat obravnavani z različnih vidikov oziroma s poudarki na različnih vsebinah. Med drugim so bili pozornosti deležni vplivi s turizmom povezanega prometa na okolje (Peeters, Szimba, Duijnisveld, 2007), vloga prometne infrastrukture in prometnih sistemov kot dejavnikov razvoja turizma (Khadaroo, Seetanah, 2007; Campodónico, da Cunha, 2010), upravljanje s turističnim/ rekreacijskim prometom (Regnerus, Beunen, Jaarsma, 2007; Ogrin, 2011), vloga prometa pri zadovoljstvu s turističnimi destinacijami (Thompson, Schofield, 2007), eksterni stroški turističnega prometa (Hall, 1999).

Turizem in prosti čas igrata pomembno vlogo kot dejavnika, ki generirata promet. S prostim časom povezan promet naj bi v industrializiranih državah znašal kar 50 \% vsega (Gössling, 2002). V Evropi zavzemajo s prostim časom pogojena potovanja okrog 40 \% vsega potovalnega časa. Dnevno posameznik namenja potovanjem, povezanim s prostim časom, povprečno od 19 minut (Madžarska) do 36 minut (Švedska). V Sloveniji je njihovo povprečno trajanje 22 minut (How Europeans spend their time ..., 2004). Že ti podatki opozarjajo na razlike med območji, ki pa seveda niso omejene le na državno raven, ampak so opazne tudi na regionalni ravni.

Največ turističnih potovanj v Evropi poteka po cesti $(61 \%)$, sledijo potovanja po zraku (21 \%), železnici (15\%) in z ladjo (3\%) (Environmental signals ..., 2001). V Sloveniji je bil leta 2010 avto uporabljen v 85,8 \% turističnih potovanj, ki niso bila pogojena s poslovnimi razlogi (ta delež je bil kar $93,1 \%$ pri potovanjih do ciljev v Sloveniji). Če upoštevamo le tista, ki so vključevala najmanj eno in največ tri prenočitve, pa je bil njegov delež 90,2 \% (Jokić, Arnež, 2011). Tudi večina tujih turistov pride po cesti - v poletni sezoni v letu 2009 je bil njihov delež 74,4 \% (Anketa o tujih turistih ..., 2009).

Obseg cestnega prometa, povezanega s turizmom, je odvisen od števila turistov in uporabljenih prometnih sredstev, zato so razlike med območji in cestnimi odseki izredno velike, saj je ponekod vloga s turizmom povezanega prometa zanemarljiva, drugod izrazito prevladujoča. Slednje velja zlasti za nekatera najpomembnejša turistična območja. Značilnosti prometa na takšnih območjih se razlikujejo od tistih na območjih, kjer turizma ni, oziroma ga je le malo. Te razlike so opazne tako glede tedenskega kot sezonskega poteka prometa (Cigale, 2007). Druga značilnost prometa na turističnih območjih je njegova povezava $z$ vremenskimi značilnostmi; različne raziskave (Brandenburg, Arnberger, 2001; Nikolopoulou, 2001; Vrtačnik Garbas, 2006) so opozorile na precejšen vpliv vremena na turistični obisk.

Turizem je pogosto prisoten na območjih, ki niso deležna samo velikega turističnega obiska, temveč so tudi razmeroma gosto poseljena. $\mathrm{V}$ takšnih primerih se postavlja 
vprašanje o dejanskem vplivu turizma na oblikovanje splošnih značilnosti prometa na takšnih območjih, saj je promet povezan tudi z drugimi gospodarskimi dejavnostmi in lokalnim prebivalstvom. Poleg tega je mogoče domnevati, da tudi na turističnih območjih niso vse ceste enako zanimive za turiste in da znotraj turističnih območij prepletanje vplivov stalnega prebivalstva in turistov oblikuje prometne tokove, pri katerih je vloga turizma zelo različna in katerih značilnosti so zelo raznolike. Ta vprašanja bodo obravnavana v pričujočem prispevku.

V Sloveniji je največja zgostitev turističnega obiska v Koprskem primorju, zato je bilo izbrano kot območje preučevanja. Namen prispevka je ugotoviti, kako in v kolikšni meri vpliva prisotnost turizma in turistov na značilnosti prometa v Koprskem primorju (občine Piran, Izola in Koper), in sicer zlasti z vidika spreminjanja obsega prometnih tokov v odvisnosti od razpoložljivosti prostega časa (čas med delovnim tednom in ob koncu tedna, v času počitnic in zunaj njih) in vremena. Prispevek obravnava tudi vprašanje, v kolikšni meri je to območje po obravnavanih značilnostih homogeno, oziroma v kolikšni meri prihaja znotraj njega do s tem povezanih razlik.

Slika 1: Števna mesta cestnega prometa v Koprskem primorju

Figure 1: Road traffic count points in Koprsko primorje

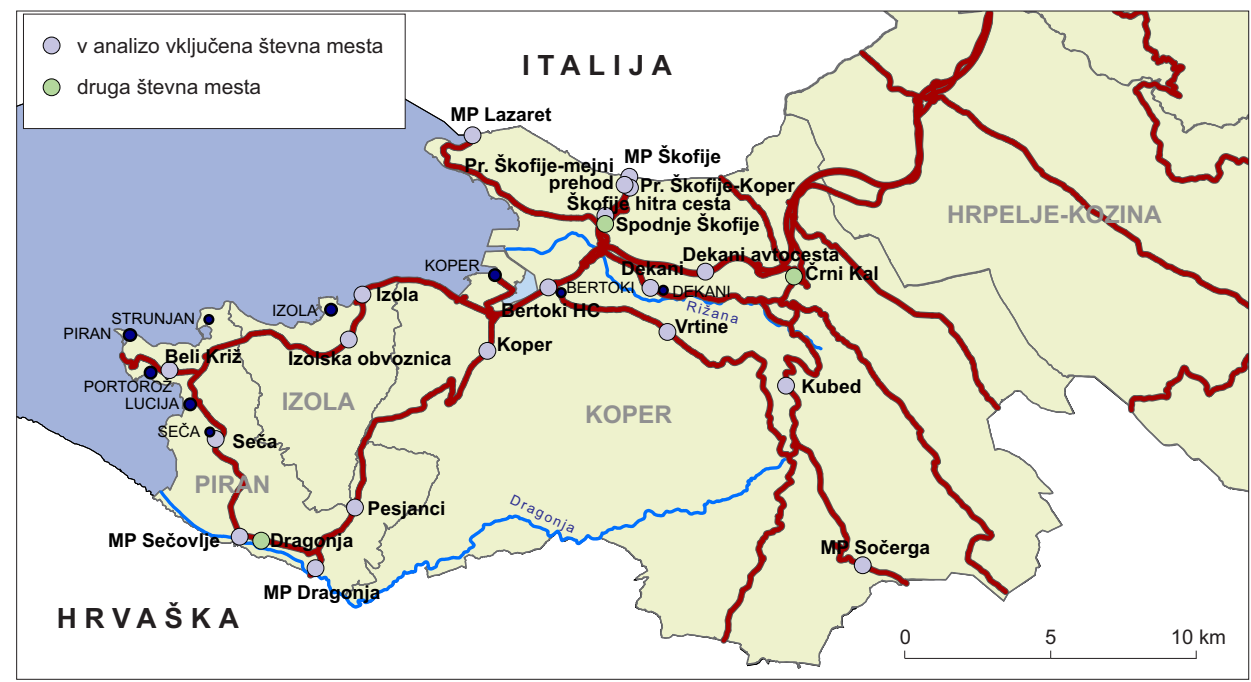

\section{TURISTIČNI OBISK IN PROMETNITOKOVIV KOPRSKEM PRIMORJU}

Območje Koprskega primorja oziroma občin Koper, Izola in Piran je glede na turistični obisk najpomembnejše slovensko turistično območje. V letu 2011 je bila po podatkih Statističnega urada Republike Slovenije (v nadaljevanju SURS) občina Piran z 1.415.137 nočitvami na prvem mestu med vsemi slovenskimi občinami, občina Izola s 360.310 nočitvami 
na sedmem in občina Koper (329.945 prenočitev) na desetem mestu. Vse tri občine so v tem letu po podatkih SURS prispevale $18,7 \%$ vseh prihodov in $22,4 \%$ vseh prenočitev v Sloveniji in to na samo 1,9 \% državnega ozemlja (Nastanitvena statistika, letni ..., 2012).

$\mathrm{Z}$ vidika vsebine prispevka je še posebej zanimiva časovna in prostorska razporeditev turističnega obiska. Glede na to, da bodo uporabljeni podatki o prometu za leto 2009, so relevantni zlasti podatki za to leto. Tako je bilo (po podatkih nove, sedaj veljavne metodologije) v letu 2009 v Koprskem primorju zabeleženih 600.022 prihodov turistov in 2.153.294 prenočitev (Nastanitvena statistika, letni ..., 2012). V dveh mesecih, ki predstavljata vrhunec poletne turistične sezone (julij, avgust), je bilo zabeleženih 32,9 \% vseh prihodov turistov (v objektih z vsaj 10 stalnimi ležišči), še večji pa je bil v istem obdobju delež prenočitev, ki je znašal kar 40,9 \% vseh prenočitev (Nastanitvena statistika, mesečni ..., 2012). To opozarja na izrazito sezonskost turističnega obiska v Koprskem primorju.

Za analizo stanja na ravni naselij so na voljo le podatki do leta 2009 , ki so bili zbrani in predstavljeni po stari, nekoliko drugačni metodologiji (Nastanitvena statistika po občinah ..., 2012). Ti podatki kažejo, da je praktično ves turistični obisk osredotočen v obalnih naseljih. O tem nas prepriča že samo primerjava števila prenočitev v vseh treh občinah Koprskega primorja in števila prenočitev v tistih obalnih naseljih, za katera je SURS do 2009 objavljal podatke o obisku v 'pomembnejših turističnih krajih' (to so Ankaran, Izola, Koper, Lucija, Piran, Portorož, Seča in Strunjan). V letu 2009 je bilo samo v teh naseljih zabeleženih 2.044.076 prenočitev (od 2.053.188 v vseh treh občinah skupaj; podatki, zbrani po stari metodologiji), kar predstavlja 99,6 \% vseh prenočitev. To nazorno opozarja na dejstvo, da predstavlja notranjost $\mathrm{z}$ vidika turizma predvsem prostor tranzita in cilj morebitnih enodnevnih izletov. Potemtakem sta za obravnavano območje značilni velika prostorska (neposredno ob obali) in časovna koncentracija obiska (izrazit višek v obeh glavnih počitniških mesecih).

Velika priljubljenost oziroma turistična obiskanost območja vpliva tudi na povečan cestni promet. Tako gre pri tem območju za eno prometno najbolj obremenjenih v Sloveniji. Cestni odsek Bertoki-Koper (Škocjan) je imel 2009 povprečni letni dnevni promet (PLDP) 52.505 vozil, s čimer je zaostajal le za nekaj odseki na območju Ljubljane (bil je osmi najbolj prometni odsek v Sloveniji; Promet 2009, 2010). Tudi po gostoti cestnega omrežja je Koprsko primorje med vodilnimi območji v Sloveniji (Lampič, Repe, 2009), prometna vloga tega območja pa se kaže tudi v nadpovprečni zastopanosti prometnega sektorja $\mathrm{v}$ gospodarstvu. Velik obseg cestnega prometa ni samo posledica prisotnosti turizma, saj gre hkrati za nadpovprečno gosto poseljeno območje $(222,4$ preb./km²; 2009), ki je tudi gospodarsko zelo dinamično, vseeno pa je turizem eden izmed pomembnejših vplivnih dejavnikov. Velik obseg prometnih tokov ni povezan le s turisti, ki na območju prenočujejo, ampak tudi z velikim številom enodnevnih obiskovalcev in turistov, namenjenih v sosednjo hrvaško Istro, ki sprejme še precej več obiskovalcev kot Koprsko primorje. Istrska županija je 2009 zabeležila 2.755.269 prihodov turistov in 18.130.006 prenočitev (Statistički ljetopis ..., 2010).

Takšne prometne obremenitve prinašajo s sabo tudi številne negativne učinke, od onesnaženja zraka (prim. Ogrin, 2008; 2009) do motenja prebivalstva zaradi hrupa. Na slednje je opozorilo tudi anketiranje prebivalcev Koprskega primorja, ki so kot najbolj negativen vpliv prometa izpostavili ravno hrup (Vintar Mally, 2009). 


\section{UPORABLJENI PODATKI IN METODE DELA}

Podatke o prometnih obremenitvah oziroma številu vozil na cestnih odsekih državnih cest zbira Direkcija Republike Slovenije za ceste in jih objavlja v vsakoletnih publikacijah (Promet 2009 - Podatki o štetju prometa ..., 2010). V njih so objavljeni tudi dnevni podatki o številu vozil za posamezna števna mesta. Zaradi tega je mogoče ugotavljati tudi odvisnost prometa od razpoložljivosti prostega časa in vremena.

Pri analizi so bili uporabljeni dnevni podatki o številu vozil za vsa števna mesta na območju občin Koper, Izola in Piran, in sicer za leto 2009; to so bili zadnji podatki, ki so bili v času analize (2011) na voljo. Izpuščeni so bili samo podatki za števna mesta z nepopolnimi podatkovnimi nizi (Črni Kal, Dragonja, Spodnje Škofije). Izjemi sta števni mesti Beli Križ in Mejni prehod Sečovlje, za kateri ravno tako niso na voljo popolni podatkovni nizi, vendar je šlo le za manjši izpad podatkov (7 oziroma 14 dni), kar ni moglo bistveno vplivati na rezultate.

Za odgovor na vprašanje, ali so značilnosti prometa na tem območju res drugačne od prometa na neturističnih območjih, so bili za primerjavo uporabljeni tudi podatki za nekatera števna mesta na izbranih slovenskih območjih, kjer turizem ni tako pomemben. Ker gre v primeru Koprskega primorja za urbanizirano in gosto poseljeno območje, so bila izbrana števna mesta na območjih Celja, Ljubljane in Murske Sobote. V Celju in Murski Soboti je turistični obisk razmeroma majhen (36.957 oziroma 27.261 prenočitev; 2009), v Ljubljani pa večji (687.605 prenočitev; Nastanitvena statistika, letni ..., 2012). V vseh treh primerih je število turistov v primerjavi s stalnimi prebivalci zelo skromno, zato ni mogoče pričakovati, da bi turizem pomembneje zaznamoval tamkajšnje prometne tokove.

Podatki o dnevnem številu vozil so bili združeni glede na ustrezna časovna obdobja (dnevi v poletni turistični sezoni in zunaj nje, dnevi ob koncu tedna/med delovnim tednom) ter glede na dnevne vrednosti vremenskih parametrov (temperatura, oblačnost, količina padavin). Pri analizi povezanosti cestnega prometa in vremena so bili uporabljeni podatki ARSO za meteorološko postajo Letališče Portorož (Meteorološki letopis 2009, 2012).

\section{NEKATERE ZNAČILNOSTI CESTNEGA PROMETA}

\section{I. Sezonska in tedenska nihanja prometa}

Na številnih turističnih območjih je najbolj očitna značilnost prometa izrazit višek števila vozil v glavni turistični sezoni. V Koprskem primorju je višek turistične sezone v juliju in avgustu, ko je tudi čas šolskih počitnic in je zabeleženih daleč največ prenočitev, zato je relevantna primerjava povprečnega dnevnega števila vozil v teh dveh mesecih in v ostalem delu leta.

Na večini števnih mestih (preglednica 1) so povprečne vrednosti za ta dva meseca bistveno višje kot v preostanku leta. Še zlasti velika je razlika na mejnih prehodih proti Hrvaški, kar tudi opozarja na veliko vlogo s turizmom povezanega tranzitnega prometa. Na teh števnih mestih so vrednosti povprečnega dnevnega prometa ( $v$ nadaljevanju PDP), tj. dnevnega števila vozil, v dvomesečni poletni sezoni več kot dvakrat tolikšne kot v preostanku leta. 
Prednjačita mejna prehoda Dragonja in Sečovlje, kjer je v poletni sezoni 2,65-krat oziroma 2,48-krat večji povprečni dnevni promet kot zunaj sezone. Da je kljub temu cestni promet povezan tudi z lokalnim prebivalstvom in njegovimi potrebami, priča dejstvo, da so na dveh števnih mestih poletne vrednosti celo malenkost nižje kot v ostalem delu leta (števni mesti Vrtine in Priključek Škofije-mejni prehod). Tudi na nekaterih drugih števnih mestih so poletne vrednosti le malo višje od zunajsezonskih (Dekani, Priključek Škofije-Koper).

Preglednica 1: Povprečni dnevni promet v poletnem času in v obdobju zunaj turistične sezone (2009)

Table 1: Average daily traffic flow in the summer season and out-of-season (2009)

\begin{tabular}{|c|c|c|c|c|}
\hline Števno mesto* & PLDP 2009 & $\begin{array}{c}\text { PDP julij + } \\
\text { avgust }\end{array}$ & $\begin{array}{l}\text { PDP zunaj sezone } \\
\text { (januar-junij, } \\
\text { september- } \\
\text { december) }\end{array}$ & $\begin{array}{c}\text { Razmerje } \\
\text { med PDP } \\
\text { v sezoni in } \\
\text { zunaj sezone }\end{array}$ \\
\hline Beli križ** & 5973 & 5923 & 5840 & 1,01 \\
\hline Bertoki-hitra cesta & 26.252 & 32.645 & 24.944 & 1,31 \\
\hline Dekani & 3767 & 4193 & 3680 & 1,14 \\
\hline Dekani-avtocesta & 22.325 & 32.790 & 20.183 & 1,62 \\
\hline Izola & 28.016 & 33.773 & 26.838 & 1,26 \\
\hline Izolska obvoznica & 8992 & 11.825 & 8413 & 1,41 \\
\hline Koper & 14.911 & 22.698 & 13.318 & 1,70 \\
\hline Kubed & 2495 & 4003 & 2186 & 1,83 \\
\hline Mejni prehod Dragonja & 7550 & 15.635 & 5895 & 2,65 \\
\hline Mejni prehod Lazaret & 1534 & 2336 & 1370 & 1,71 \\
\hline Mejni prehod Sečovlje** & 4214 & 8007 & 3235 & 2,48 \\
\hline Mejni prehod Sočerga & 1796 & 3394 & 1469 & 2,31 \\
\hline Mejni prehod Škofije & 17.935 & 21.316 & 17.243 & 1,24 \\
\hline Pesjanci & 9985 & 18.545 & 8234 & 2,25 \\
\hline Priključek Škofije-Koper & 558 & 634 & 542 & 1,17 \\
\hline Priključek Škofije-mejni prehod & 4506 & 4391 & 4530 & 0,97 \\
\hline Seča & 9556 & 13.273 & 8795 & 1,51 \\
\hline Škofije - hitra cesta & 13.986 & 17.558 & 13.255 & 1,32 \\
\hline Vrtine & 5107 & 5029 & 5123 & 0,98 \\
\hline
\end{tabular}

Vir/Source: Promet 2009 - Podatki o štetju prometa ..., 2010

* Poimenovanje števnih mest je povzeto po podatkih Direkcije RS za ceste.

** Za števno mesto Mejni prehod Sečovlje manjkajo podatki za 14 dni, za Beli Križ za 7 dni.

Za tedenska nihanja obsega prometa so značilni viški ob koncih tedna (preglednica 2). $\mathrm{K}$ njim prispevajo tako enodnevni izleti kot tudi krajša turistična potovanja (vključno z bivanjem v počitniških bivališčih), ki vključujejo oba dneva ob koncu tedna, lahko pa tudi 
že petkovo popoldne. Podatki kažejo na povečan promet ali (na nekaterih števnih mestih) celo viške prometa že ob petkih, zato pri primerjavi PDP ob koncu tedna in med tednom petki niso bili upoštevani, saj ob petkih vsaj deloma prihaja do prekrivanja prostočasnega in neprostočasnega prometa. $\mathrm{V}$ preglednici 2 predstavljeni podatki za dneve med tednom tako zajemajo samo dneve od ponedeljka do četrtka. Na ta način so prišli bolj do izraza vplivi tistih dejavnikov, ki povzročajo razlike v obsegu cestnega prometa med delovnim tednom in ob koncu tedna.

Preglednica 2: Povprečni dnevni promet med delovnim tednom in ob koncu tedna (2009) Table 2: Average daily traffic flow during working days (Monday to Thursday) and on weekends (2009)

\begin{tabular}{|l|c|c|c|}
\hline Števno mesto & $\begin{array}{c}\text { PDP konec tedna } \\
\text { (vključno s prazniki) }\end{array}$ & $\begin{array}{c}\text { PDP med tednom } \\
\text { (ponedeljek-četrtek) }\end{array}$ & $\begin{array}{c}\text { Razmerje med PDP } \\
\text { V dneh ob koncu } \\
\text { tedna in med tednom }\end{array}$ \\
\hline Beli križ & 5202 & 6027 & 0,86 \\
\hline Bertoki-hitra cesta & 23.052 & 26.713 & 0,86 \\
\hline Dekani & 3467 & 3815 & 0,91 \\
\hline Dekani-avtocesta & 23.187 & 20.966 & 1,11 \\
\hline Izola & 25.684 & 28.394 & 0,90 \\
\hline Izolska obvoznica & 8802 & 8708 & 1,01 \\
\hline Koper & 15.354 & 14.169 & 1,08 \\
\hline Kubed & 3038 & 2109 & 1,44 \\
\hline Mejni prehod Dragonja & 9800 & 6149 & 1,59 \\
\hline Mejni prehod Lazaret & 2012 & 1295 & 1,55 \\
\hline Mejni prehod Sečovlje & 5150 & 3359 & 1,53 \\
\hline Mejni prehod Sočerga & 2461 & 1365 & 1,80 \\
\hline Mejni prehod Škofije & 18.175 & 17.334 & 1,05 \\
\hline Pesjanci & 11.855 & 8674 & 1,37 \\
\hline Priključek Škofije-Koper & 485 & 577 & 0,84 \\
\hline Priključek Škofije-mejni prehod & 4685 & 4311 & 1,09 \\
\hline Seča & 9834 & 9196 & 1,07 \\
\hline Škofije- hitra cesta & 13.975 & 13.600 & 1,03 \\
\hline Vrtine & 4337 & 5377 & 0,81 \\
\hline
\end{tabular}

Vir/Source: Promet 2009 - Podatki o štetju prometa ..., 2010

Razmerje med povprečnim dnevnim prometom ob koncu tedna in med (reduciranim) delovnim tednom v večini primerov pokaže na precejšnje razlike v obsegu prometa, ki pa niso tako velike kot pri sezonskih gibanjih. Promet ob koncu tedna najbolj presega promet med tednom na mejnem prehodu Sočerga (povprečno število vozil ob koncu tedna 
je 1,8-krat večje kot v dneh od ponedeljka do četrtka), sledita mejna prehoda Dragonja $(1,59)$ in Lazaret $(1,55)$. Na šestih števnih mestih je bil PDP ob koncu tedna nekoliko manjši. Najbolj je promet med tednom presegal tistega ob koncih tedna na števnem mestu Vrtine, kjer ni bilo mogoče opaziti niti poletnega viška prometa.

\subsection{Povezanost prometa in vremena}

Druga značilnost cestnega prometa, ki jo je mogoče pričakovati na tako turističnem območju kot je Koprsko primorje, je njegova povezanost z vremenskim stanjem. Vreme in podnebje sta pomembna za turizem in turiste $\mathrm{z}$ različnih vidikov, od sezonskosti turističnega obiska do vpliva na ugodje turistov (Gómez Martín, 2005). Že pri površnem opazovanju prometa na turističnih območjih je opazen vpliv lepega (sončnega, toplega) vremena na povečan obisk. Opravljene raziskave so to nedvoumno potrjevale. Brandenburg, Arnberger (2001) sta ugotavljala, da je imel sicer največji vpliv na število prostočasnih obiskovalcev (večinoma enodnevnih oziroma nekajurnih) dan v tednu, pomemben pa je bil tudi vpliv fiziološke ekvivalentne temperature, še zlasti za kolesarje in pohodnike/ sprehajalce. Vpliv padavin in oblačnosti je bil zmeren. Nikolopoulou (2001) je ugotovila, da sončna svetloba in višje temperature pomembno vplivajo na povprečno število ljudi, ki uporabljajo odprte prostore v urbanem okolju, vendar se je porast števila ustavil pri okrog $25{ }^{\circ} \mathrm{C}$. Podobno je Vrtačnik Garbas (2006) na primeru različnih slovenskih turističnih točk (Krvavec, Logarska dolina, slap Savica, Velika planina) ugotovila večji obisk ob lepem vremenu. Izjema je bila Postojnska jama, za obisk katere lepo vreme ni potrebno.

Pri analizi stanja v Koprskem primorju so bile upoštevane tiste značilnosti vremena, ki bi lahko pomembneje vplivale na turistični obisk in s tem na cestni promet. Medtem ko je del turističnih potovanj zlasti v poletni sezoni vezan na vnaprejšnje rezervacije prenočišč in potemtakem $v$ precejšnji meri neodvisen od trenutnega vremena, je drugi del turističnih potovanj posledica kratkoročnih odločitev, na katere pa vplivajo tudi informacije o pričakovanem ali dejanskem vremenu.

Pri izboru kazalcev (vremenskih parametrov) je bilo pomembno, kaj lahko potencialni turist izve o pričakovanem vremenu iz vremenske napovedi, saj ravno to vpliva na njegovo ravnanje oziroma na odločitev za prostočasno potovanje/obisk določenega območja. Pri tem gre predvsem za informacije o temperaturah, oblačnosti in padavinah. Redko oziroma nesistematično so v napoved vključene še druge informacije, npr. močan veter ali velika toplotna obremenitev. Iz navedenega razloga npr. ni bil upoštevan fiziološki ekvivalent temperature (kot sta ga uporabila Brandenburg, Arnberger, 2001), saj predstavlja sintezno informacijo in ga širša javnost ne pozna in ne srečuje v medijih. Poleg vremenske napovedi lahko zlasti na enodnevni ali konectedenski obisk vplivajo tudi informacije o trenutnem vremenu. Tako se lahko npr. prebivalec Ljubljane zjutraj odloči za obisk Koprskega primorja, ko sliši na radiu ali vidi na medmrežju informacijo o lepem vremenu v Portorožu.

Spreminjanje temperatur je povezano zlasti s sezonskimi nihanji. Znotraj ene sezone ni mogoče pričakovati ekstremno nizkih in ekstremno visokih vrednosti. Drugače je s padavinami in oblačnostjo, saj so lahko v enem samem letnem času (ali mesecu ali celo dnevu) prisotna 
tako obdobja popolnoma jasnega kot popolnoma oblačnega vremena, enako obdobja z veliko intenziteto padavin kot brez njih. Zaradi navedenega slednja dva vremenska parametra (oblačnost, padavine) predvidoma bolj vplivata na nihanja turističnega obiska znotraj določene sezone ali meseca, medtem ko so pri temperaturi tovrstne povezave manj izrazite.

Da bi ugotovili, v kolikšni meri je mogoče opaziti vpliv vremena na promet, smo primerjali podatke o dnevnem številu vozil s podatki za meteorološko postajo Letališče Portorož. Gre za edino meteorološko postajo na obravnavanem območju, za katero redno objavljajo podatke tudi v medijih (radio, nekatere spletne strani ...).

Koprsko primorje ima submediteransko podnebje (podtipa obalnega in zalednega submediteranskega podnebja; Ogrin, 1996). Po podatkih ARSO (Agencije RS za okolje) je na letališču Portorož povprečna letna količina padavin (obdobje 1961-1990) 1046 mm, srednja letna temperatura pa $13,5^{\circ} \mathrm{C}$ (najtoplejši je julij, najhladnejši januar; Klimatski podatki - Portorož, 2013).

V letu 2009 je na meteorološki postaji na letališču Portorož padlo 931,8 mm padavin, največ decembra (202,8 mm), najmanj julija (21,0 mm; Meteorološki letopis ..., 2011). Zabeleženih je bilo 155 dni s padavinami, 118 dni s padavinami nad $0,1 \mathrm{~mm}$, le 86 dni pa je imelo vsaj $1 \mathrm{~mm}$ padavin. Najvišja dnevna količina padavin $(76,3 \mathrm{~mm})$ je bila 21. junija. Najmanj oblačen je bil avgust (mesečno povprečje 2, tako ob 7. kot ob 14. uri), najbolj oblačen pa november (mesečno povprečje 8 , tako ob 7. kot ob 14. uri). Povprečna maksimalna dnevna temperatura je bila najnižja januarja $\left(9,2{ }^{\circ} \mathrm{C}\right)$, najvišja avgusta $\left(30,9^{\circ} \mathrm{C}\right)$.

Podatke o dnevnem prometu smo primerjali z naslednjimi vremenskimi parametri za ustrezni dan: maksimalna temperatura, oblačnost ob 7. uri, oblačnost ob 14. uri in količina padavin. Pri primerjavi dnevnega prometa in oblačnosti ob 7. in 14. uri so si bili rezultati podobni, nekoliko manj očitna je bila povezanost med dnevnim prometom in dnevno količino padavin. Zaradi omejenega prostora bodo v nadaljevanju predstavljeni le podatki o PDP glede na oblačnost ob 14. uri in maksimalno dnevno temperaturo. Prvi kažejo zlasti na nihanja cestnega prometa pri turističnih potovanjih ob koncih tedna, drugi pa tudi na nihanja, povezana s sezonskimi spremembami turističnega obiska.

$\mathrm{V}$ preglednici 3 je predstavljen povprečni dnevni promet ob najbolj jasnih dnevih (oblačnost od 0 do 2) ter v najbolj oblačnih dnevih (oblačnost od 8 do 10). Podatki za vsa števna mesta kažejo opazne razlike v vrednostih PDP: najmanjše so na števnem mestu Priključek Škofije--mejni prehod, največje pa pri števnih mestih Mejni prehod Dragonja (PDP ob najbolj jasnih dnevih je 1,67-krat večji kot ob najbolj oblačnih dnevih) in Mejni prehod Sečovlje (1,60). Števna mesta, kjer je bilo v letnem povprečju (2009) ob jasnih dneh za več kot polovico več vozil kot ob najbolj oblačnih dnevih, so bila kar štiri (poleg že omenjenih še Mejni prehod Sočerga ter Pesjanci).

Podatki torej kažejo določen vpliv oblačnosti na obseg cestnega prometa. Za dodaten vpogled v odnos med oblačnostjo in prometom smo izračunali še statistično povezanost med dnevnim številom vozil na posameznih števnih mestih in oblačnostjo na enajststopenjski lestvici (preglednica 3). Zaradi narave podatkov (izrazito nenormalna, asimetrična distribucija podatkov o oblačnosti, pa tudi podatkov o PDP na nekaterih števnih mestih) je bila za ugotavljanje povezanosti uporabljena neparametrična metoda, in sicer Spearmanov koeficient korelacije ranga. 
Rezultati so pričakovano pokazali negativno povezanost (upadanje števila vozil s povečevanjem oblačnosti) v vseh primerih, z (delno) izjemo števnega mesta Priključek Škofije-mejni prehod. Stopnja povezanosti ni zelo visoka, a je vseeno očitna. Pričakovati je mogoče, da je na nekoliko manjšo povezanost vplivalo tudi mešanje prostočasnega in neprostočasnega prometa. Najvišja stopnja povezanosti je bila opazna pri števnem mestu Mejni prehod Lazaret $(-0,437)$.

Preglednica 3: Povprečni dnevni promet na števnih mestih v Koprskem primorju $v$ dneh z različno stopnjo oblačnosti ob 14. uri

Table 3: Average daily traffic flow for road traffic count points in Koprsko primorje on days with a different degree of cloudiness at 2:00 P.M.

\begin{tabular}{|l|c|c|c|c|}
\hline Števno mesto & $\begin{array}{c}\text { PDP v dneh } \\
\text { z oblačnostjo } \\
\mathbf{0 - 2}\end{array}$ & $\begin{array}{c}\text { PDP v dneh } \\
\text { z oblačnostjo } \\
\mathbf{8}-\mathbf{1 0}\end{array}$ & $\begin{array}{c}\text { Razmerje med } \\
\text { PDP v dneh z } \\
\text { oblačnostjo 0-2 in } \\
\mathbf{8 - 1 0}\end{array}$ & $\begin{array}{c}\text { Povezanost } \\
\text { oblačnosti in } \\
\text { PDP (r) }\end{array}$ \\
\hline Mejni prehod Lazaret & 1805 & 1211 & 1,49 & $-0,437^{* *}$ \\
\hline Izolska obvoznica & 9824 & 7968 & 1,23 & $-0,416^{* *}$ \\
\hline Dekani & 3958 & 3499 & 1,13 & $-0,416^{* *}$ \\
\hline Dekani-avtocesta & 24.975 & 19.072 & 1,31 & $-0,410^{* *}$ \\
\hline Seča & 10.492 & 8435 & 1,24 & $-0,395^{* *}$ \\
\hline Beli križ & 6309 & 5564 & 1,13 & $-0,381^{* *}$ \\
\hline Kubed & 2832 & 2080 & 1,36 & $-0,378^{* *}$ \\
\hline Koper & 16.697 & 12.748 & 1,31 & $-0,377^{* *}$ \\
\hline Škofije- hitra cesta & 15.025 & 12.753 & 1,18 & $-0,377^{* *}$ \\
\hline Pesjanci & 11.879 & 7768 & 1,53 & $-0,366^{* *}$ \\
\hline Mejni prehod Sočerga & 2141 & 1382 & 1,55 & $-0,366^{* *}$ \\
\hline Mejni prehod Dragonja & 9250 & 5543 & 1,67 & $-0,362^{* *}$ \\
\hline Izola & 29.701 & 25.930 & 1,15 & $-0,361^{* *}$ \\
\hline Mejni prehod Sečovlje & 5108 & 3184 & 1,60 & $-0,352^{* *}$ \\
\hline Bertoki-hitra cesta & 28.003 & 24.046 & 1,16 & $-0,346^{* *}$ \\
\hline Mejni prehod Škofije & 18.934 & 16.673 & 1,14 & $-0,342^{* *}$ \\
\hline Priključek Škofije-Koper & 573 & 538 & 1,07 & $-0,169^{* * *}$ \\
\hline Vrtine & 5199 & 4956 & 1,05 & $-0,158^{* *}$ \\
\hline Priključek Škofije-mejni prehod & 4482 & 4458 & 1,01 & $-0,037$ \\
\hline
\end{tabular}

Vir/Source: Promet 2009 - Podatki o štetju prometa ..., 2010

** Povezava je statistično pomembna pri stopnji tveganja $\alpha=0,01$.

Že podatki o velikih razlikah v PDP v času sezone in zunaj nje (preglednica 1) nakazujejo, da bo prisotna tudi povezanost med temperaturami in prometom. Dneve z visokimi temperaturami najdemo zlasti v času poletne sezone in v 'sosednjih' mesecih, nižje 
temperature pa so prisotne v času zunaj turistične sezone. Sklepamo lahko, da nihanja prometa bolj kažejo na sezonske vremenske vplive kot pa na vplive razmeroma kratkotrajnih sprememb vremena (glede na temperature), ki pa so pomembne zlasti za enodnevni in konectedenski prostočasni promet.

Preglednica 4: Povprečni dnevni promet na števnih mestih $v$ Koprskem primorju $v$ dneh z različno maksimalno dnevno temperaturo

Table 4: Average daily traffic flow for road traffic count points in Koprsko primorje on days with different maximum temperatures

\begin{tabular}{|c|c|c|c|c|}
\hline Števno mesto & $\begin{array}{l}\text { PDP v dneh } \mathrm{s} \\
T_{\max } \leq 10^{\circ} \mathrm{C}\end{array}$ & $\begin{array}{l}\text { PDP v dneh s } \\
T_{\max }>20^{\circ} \mathrm{C}\end{array}$ & $\begin{array}{c}\text { Razmerje med } \\
\text { PDP v dneh s } \\
T_{\max }>20^{\circ} \mathrm{C} \text { in } \\
T_{\max } \leq 10^{\circ} \mathrm{C}\end{array}$ & $\begin{array}{c}\text { Povezanost } \\
\text { temperatur in } \\
\text { PDP (r) }\end{array}$ \\
\hline Beli križ & 5066 & 6437 & 1,27 & $0,594^{* *}$ \\
\hline Bertoki-hitra cesta & 21.224 & 29.480 & 1,39 & $0,725^{* *}$ \\
\hline Dekani & 3223 & 4061 & 1,26 & $0,641^{* *}$ \\
\hline Dekani-avtocesta & 15.714 & 27.235 & 1,73 & $0,846^{* *}$ \\
\hline Izola & 23.056 & 31.176 & 1,35 & $0,806^{* *}$ \\
\hline Izolska obvoznica & 7070 & 10.383 & 1,47 & $0,788^{* *}$ \\
\hline Koper & 10.299 & 18.542 & 1,80 & $0,869^{* *}$ \\
\hline Kubed & 1684 & 3146 & 1,87 & $0,788^{* *}$ \\
\hline Mejni prehod Dragonja & 3645 & 11.056 & 3,03 & $0,839 * *$ \\
\hline Mejni prehod Lazaret & 1105 & 1921 & 1,74 & $0,697 * *$ \\
\hline Mejni prehod Sečovlje & 2250 & 5966 & 2,65 & $0,816^{* *}$ \\
\hline Mejni prehod Sočerga & 1022 & 2476 & 2,42 & $0,775^{* *}$ \\
\hline Mejni prehod Škofije & 15.659 & 19.652 & 1,25 & $0,658 * *$ \\
\hline Pesjanci & 5531 & 13.822 & 2,50 & $0,858^{* *}$ \\
\hline Priključek Škofije-Koper & 496 & 598 & 1,21 & $0,421^{* *}$ \\
\hline Priključek Škofije-mejni prehod & 4428 & 4513 & 1,02 & 0,08 \\
\hline Seča & 7200 & 11.330 & 1,57 & $0,853 * *$ \\
\hline Škofije - hitra cesta & 11.727 & 15.737 & 1,34 & $0,746^{* *}$ \\
\hline Vrtine & 4576 & 5271 & 1,15 & $0,270^{* *}$ \\
\hline
\end{tabular}

Vira/Sources: Promet 2009 - Podatki o štetju prometa ..., 2010; Meteorološki letopis 2009, 2012 ** Povezava je statistično pomembna pri stopnji tveganja $\alpha=0,01$.

V preglednici 4 je prikazana primerjava prometa $\mathrm{v}$ dneh $\mathrm{s}$ hladnejšim (najvišja dnevna temperatura $\left.\leq 10^{\circ} \mathrm{C}\right)$ in toplejšim vremenom $\left(>20^{\circ} \mathrm{C}\right)$. Podatki pričakovano pokažejo zelo velike razlike v številu vozil (PDP) v odvisnosti od temperature. Primerjava PDP v dneh z maksimalnimi temperaturami nad $20^{\circ} \mathrm{C}$ in pod $10{ }^{\circ} \mathrm{C}$ pokaže, da so razlike tudi več kot dvakratne, na števnem mestu Mejni prehod Dragonja pa je PDP ob toplejših 
dnevih (najvišja dnevna temperatura $>20^{\circ} \mathrm{C}$ ) celo 3,03-krat večji kot v hladnejših dnevih $\mathrm{z}$ najvišjo dnevno temperaturo $\leq 10^{\circ} \mathrm{C}$ ).

Visoko povezanost med PDP in najvišjimi dnevnimi temperaturami pokaže tudi Spearmanov koeficient korelacije ranga, saj v več primerih (Seča, Mejni prehod Dragonja, Koper, Pesjanci, Mejni prehod Sečovlje, Izola, Dekani - avtocesta) presega 0,8. Edino izjemo spet predstavlja števno mesto Priključek Škofije-mejni prehod, kjer med tema parametroma ni nikakršne povezave.

\section{PRIMERJAVA Z DRUGIMI OBMOČJI}

Analiza podatkov o povprečnem dnevnem prometu je pokazala precejšnja nihanja PDP, povezana $\mathrm{z}$ razpoložljivostjo prostega časa (večji promet $\mathrm{v}$ času dopustov in ob koncu tedna) ter vremenom (več prometa ob bolj jasnih, brezpadavinskih in toplejših dneh). Samo iz njih pa še ni razvidno, v kolikšni meri gre za posebnost obravnavanega turističnega območja in v kolikšni meri morebiti za splošne značilnosti, ki so prisotne tudi na drugih območjih, kjer turizma ni oziroma je bistveno manj pomemben.

Preglednica 5: Povprečni dnevni promet na izbranih števnih mestih na neturističnih območjih $v$ času poletne turistične sezone in zunaj nje (2009)

Table 5: Average daily traffic flow for selected road traffic count points in non-tourist areas in the summer season and out-of-season (2009)

\begin{tabular}{|l|c|c|c|}
\hline Števno mesto & PLDP 2009 & $\begin{array}{c}\text { Razmerje med PDP } \\
\text { v sezoni in zunaj } \\
\text { sezone }\end{array}$ & $\begin{array}{c}\text { Razmerje med PDP } \\
\text { ob koncih tedna* in } \\
\text { med tednom** }\end{array}$ \\
\hline Murska Sobota-sever & 11.859 & 1,03 & 0,72 \\
\hline Murska Sobota- Bakša & 12.053 & 0,95 & 0,57 \\
\hline Celje - Lava & 13.568 & 0,93 & 0,62 \\
\hline Celje- Teharje & 17.190 & 0,96 & 0,58 \\
\hline Ljubljana-severna vpadnica & 34.716 & 0,87 & 0,47 \\
\hline Ljubljana - severna obvoznica & 32.598 & 0,94 & 0,57 \\
\hline Ljubljana Dravlje- hitra cesta & 30.661 & 0,97 & 0,53 \\
\hline Ljubljana Celovška-Dravlje & 43.219 & 0,84 & 0,66 \\
\hline
\end{tabular}

Vir/Source: Promet 2009 - Podatki o štetju prometa ..., 2010

*Vključno s prazniki.

** Dnevi od ponedeljka do četrtka.

Da bi ugotovili, v kolikšni meri je predstavljena situacija v Koprskem primorju specifična, smo analizirali še podatke za nekaj števnih mest v notranjosti Slovenije. Kot že omenjeno, so bila izbrana števna mesta na tistih urbaniziranih območjih, kjer ni bilo pričakovati pomembnejšega s turizmom pogojenega cestnega prometa - ali zato, ker je turistični obisk razmeroma skromen, ali ker je število turistov bistveno manjše od števila 
stalnih prebivalcev. Izbrana so bila števna mesta s treh urbanih območij, in sicer Ljubljane, Celja in Murske Sobote. Uporabili smo enake podatke o prometu in vremenu in napravili enake izračune kot v primeru Koprskega primorja.

Podatki v preglednici 5 kažejo bistveno drugačno podobo kot v Koprskem primorju. Sezonska nihanja prometa so le malo izrazita, v nekaterih primerih (Ljubljana Celovška - Dravlje, Ljubljana - severna vpadnica) pa PDP v poletni sezoni (julij, avgust) celo bistveno zaostaja za letnim povprečjem (tj. PLDP). Tudi nihanja prometa preko tedna so bistveno drugačna. Namesto viška ob koncih tedna je ob sobotah in nedeljah v vseh primerih bistveno manjši povprečni dnevni promet kot $\mathrm{v}$ dneh od ponedeljka do četrtka.

Preglednica 6: Povprečni dnevni promet glede na izbrane vremenske parametre na števnih mestih na območju Celja, Ljubljane in Murske Sobote (2009)

Table 6: Average daily traffic flow (2009) for road traffic count points in the Celje, Ljubljana and Murska Sobota area with regard to selected weather parameters

\begin{tabular}{|c|c|c|c|c|c|}
\hline Števno mesto & $\begin{array}{c}\text { PLDP } \\
2009\end{array}$ & $\begin{array}{c}\text { Razmerje } \\
\text { med PDP } \\
\mathrm{v} \text { dnevih s } \\
\mathrm{T}_{\max }>20 \text { in } \\
\text { dnevih } \mathrm{s}_{\mathrm{T}_{\max }} \\
\quad \leq 10 \\
\end{array}$ & $\begin{array}{l}\text { Razmerje med } \\
\text { PDP v dnevih } \\
\text { z najmanjšo } \\
\text { (0-2) in } \\
\text { največjo (8-10) } \\
\text { oblačnostjo }\end{array}$ & $\begin{array}{c}\text { Povezanost } \\
\text { med } T_{\max } \text { in } \\
\operatorname{PDP}\left(r_{s}\right)\end{array}$ & $\begin{array}{c}\text { Povezanost } \\
\text { med } \\
\text { oblačnostjo } \\
\text { ob 14. uri in } \\
\text { PDP }\left(r_{s}\right)\end{array}$ \\
\hline Murska Sobota - sever & 11.859 & 1,1 & 1,04 & $0,325^{* *}$ & $-0,166^{* *}$ \\
\hline Murska Sobota - Bakša & 12.053 & 1,01 & 0,99 & $-0,007$ & 0,035 \\
\hline Celje - Lava & 13.568 & 1,02 & 0,99 & 0,038 & 0,043 \\
\hline Celje-Teharje & 17.190 & 1,03 & 0,99 & 0,068 & 0,039 \\
\hline Ljubljana - severna vpadnica & 34.716 & 0,98 & 0,98 & $-0,059$ & 0,017 \\
\hline Ljubljana - severna obvoznica & 32.598 & 1,05 & 1,02 & 0,058 & $-0,037$ \\
\hline Ljubljana Dravlje - hitra cesta & 30.661 & 1,07 & 1,03 & $0,127^{*}$ & $-0,07$ \\
\hline Ljubljana Celovška - Dravlje & 43.219 & 0,95 & 0,97 & $-0,115^{*}$ & 0,053 \\
\hline
\end{tabular}

Vira/Sources: Promet 2009 - Podatki o štetju prometa ..., 2010; Meteorološki letopis 2009, 2012 ** Povezava je statistično pomembna pri stopnji tveganja $\alpha=0,01$.

Medtem ko je bil vpliv vremena na promet na območju Koprskega primorja zelo očiten, na števnih mestih z območij Celja, Ljubljane in Murske Sobota te povezave iz podatkov - razen izjemoma - ni opaziti (preglednica 6). V vseh primerih je obseg prometa podoben tako v najbolj oblačnih kot najbolj jasnih dneh. Prav tako ni večjih razlik v obsegu prometa med najbolj toplimi in najbolj hladnimi dnevi. Tudi izračun Spearmanovega koeficienta korelacije $\left(\mathrm{r}_{\mathrm{s}}\right.$ ) povezav ni pokazal ali pa so bile (v redkih primerih) zelo skromne. Za ponazoritev lahko služita grafikona (sliki 2 in 3), ki kažeta očitne razlike v povezanosti dnevnega prometa in najvišjih dnevnih temperatur med števnima mestoma Mejni prehod Dragonja in Ljubljana - severna vpadnica, od katerih je prvo na izrazito turističnem območju, drugo pa ne. 
Slika 2: Povezava dnevnega števila vozil in najvišje dnevne temperature (števno mesto Mejni prehod Dragonja;2009)

Figure 2: Correlation between average daily number of vehicles and maximum daily temperatures (road traffic count point Dragonja border crossing; 2009)

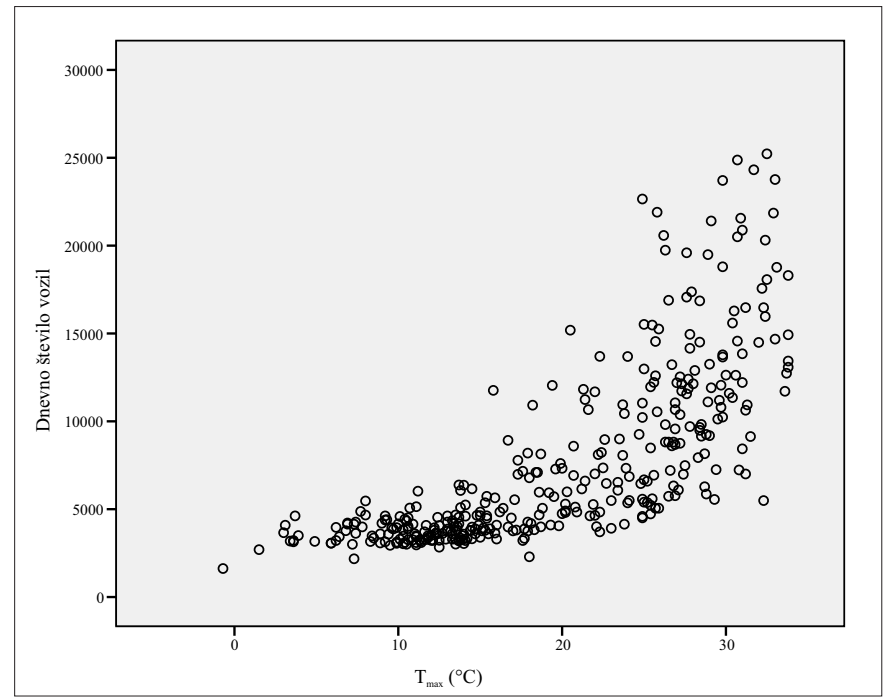

Slika 3: Povezava dnevnega števila vozil in najvišje dnevne temperature (števno mesto Ljubljana - severna vpadnica; 2009)

Figure 3: Correlation between average daily number of vehicles and maximum daily temperatures (road traffic count point Ljubljana - northern radial road; 2009)

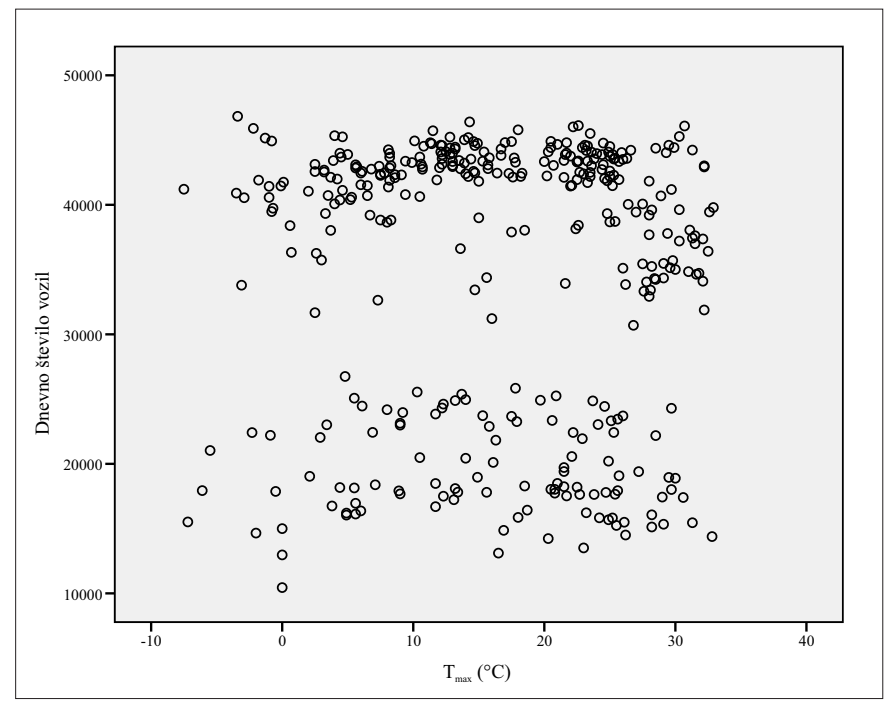




\section{NOTRANJA RAZČLENJENOST OBRAVNAVANEGA OBMOČJA}

Primerjava podatkov o PDP za območje Koprskega primorja in izbrana urbana območja v notranjosti jasno kaže, da prometno situacijo na obravnavanem območju bistveno oblikuje turizem, saj so značilnosti poteka prometa opazno drugačne. Po drugi strani pa predstavljeni podatki opozarjajo, da so glede intenzivnosti vplivov turizma tudi znotraj Koprskega primorja pomembne razlike.

Obravnavane značilnosti prometa nesporno govorijo o intenzivnosti vplivov turizma na obseg prometnih tokov, zato bi bilo mogoče na tej osnovi sklepati, kje so s turizmom pogojeni prometni tokovi bolj ali manj pomembni oziroma, na katerih cestnih odsekih ima turizem kot povzročitelj cestnega prometa večjo vlogo.

$\mathrm{Ob}$ upoštevanju podatkov o PDP ob koncih tedna in med tednom ter med glavno turistično sezono (julij-avgust) in zunaj nje so bila $v$ ta namen števna mesta $v$ Koprskem primorju razdeljena $\mathrm{v}$ tri skupine: števna mesta $\mathrm{z}$ izrazitimi viški prometa poleti (PDP vsaj 1,7-krat tolikšen kot v ostalih mesecih) in ob koncih tedna (PDP vsaj 1,3-krat večji kot med tednom), števna mesta $\mathrm{z}$ dokaj enakomernim PDP tekom tedna in leta (PDP poleti do 1,3-krat večji kot v ostalem letu, PDP ob koncih tedna nižji kot med tednom) ter ostala števna mesta. Števna mesta prve skupine so na cestnih odsekih, kjer je vloga s turizmom pogojenega cestnega prometa prevladujoča, v drugi skupini so števna mesta, na katerih je pomembnejša vloga prometa, ki ga povzroča lokalno prebivalstvo in ni prostočasno pogojen, števna mesta tretje skupine pa predstavljajo prehodni tip (slika 4).

Slika 4: Števna mesta v Koprskem primorju glede na časovno razporeditev prometa Figure 4: Road traffic count points of daily traffic flow in Koprsko primorje with regard to time distribution of traffic volumes

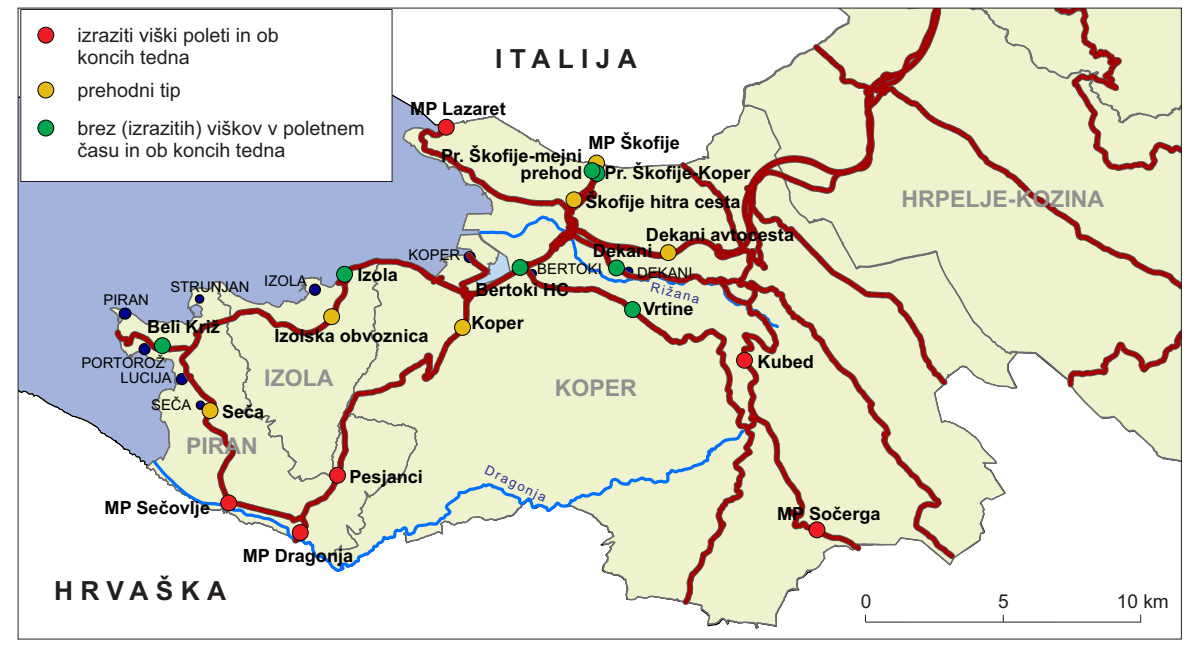

Vir/Source: Promet 2009 - Podatki o štetju prometa ..., 2010 
V prvo skupino sodijo mejni prehodi (Sečovlje, Dragonja, Sočerga, Lazaret) ter dve števni mesti na cestah proti mejnim prehodom ali pa so na redkeje poseljenih območjih (Kubed, Pesjanci), kjer je lokalno pogojenega prometa relativno malo. To kaže, da je turistični obisk hrvaške Istre pomembnejši dejavnik povečanja cestnega prometa kot turistični obisk slovenskih obmorskih krajev. Na drugi strani imamo števna mesta z manjšim nihanjem prometa, povezanega $\mathrm{z}$ razpoložljivim prostim časom, ki so predvsem na najgosteje poseljenih območjih, kjer je večina prometa povezana $\mathrm{z}$ aktivnostmi lokalnega prebivalstva. V to skupino sodijo števna mesta Beli Križ, Izola, Bertoki - hitra cesta, Priključek Škofije-mejni prehod, Priključek Škofije-Koper. V tej skupini sta tudi števni mesti Dekani in Vrtine, ki ne ležita na pomembnejših tranzitnih poteh, zato je tam prisoten predvsem lokalni promet.

\section{SKLEP}

Koprsko primorje je najbolj obiskano turistično območje v Sloveniji. Med posledicami velikega turističnega obiska so tudi bistveno drugačne značilnosti prometa (glede na nihanja obsega prometa) kot na neturističnih območjih. Kljub temu ta vpliv ni tolikšen, da bi popolnoma prekril oziroma zabrisal vplive lokalnega prebivalstva. Potemtakem celo na območju z največjo koncentracijo turističnega obiska $\mathrm{v}$ državi prisotnost (številnega) lokalnega prebivalstva vpliva na to, da na nekaterih števnih mestih posebne, s turizmom pogojene značilnosti prometa ne pridejo bolj do izraza, oziroma vpliv turizma zaostaja za vplivom lokalnega prebivalstva.

V Koprskem primorju je $\mathrm{v}$ letnem povprečju razmerje med številom stalnih prebivalcev in povprečnim dnevnim številom turistov približno $15: 1$ (2011). Prebivalci torej turiste po številu občutno prekašajo. Iz tega bi bilo mogoče sklepati, da vpliv turizma na cestni promet ne more biti posebno pomemben. Analiza podatkov o cestnem prometu pa pokaže, da bi bil tak sklep preuranjen, saj pri tem niso upoštevani enodnevni obiskovalci in tranzitni promet proti Hrvaški. S tega vidika je analiza podatkov o cestnem prometu (bolje) opozorila na nekatere značilnosti turizma (prisotnost enodnevnega izletniškega turizma, nihanja turističnega obiska tudi znotraj posameznih mesecev) in njegovih vplivov na območju kot prikazujejo podatki SURS, ki se nanašajo zgolj na turistične prenočitve in so dostopni le za posamezne mesece in leta. Potemtakem bi bilo obravnavanje prometa na turističnih območjih pomanjkljivo, če ne bi upoštevali tudi vloge lokalnega prebivalstva, saj to pomembno prispeva tudi k problemom, ki se pojavljajo.

Čeprav ni bilo posebej omenjeno, na opisane značilnosti prometa vplivajo tudi domačini s svojimi prostočasnimi potrebami, pri čemer je mogoče pričakovati podobno časovno razporeditev prometa (viški ob koncu tedna, poleti, ob lepem vremenu) kot pri prostočasno pogojenem prometu nasploh. Tovrsten vpliv lokalnega prebivalstva se na uporabljenih podatkih o cestnem prometu kaže le deloma, saj lahko domačini številne prostočasne aktivnosti (npr. kopanje $\mathrm{v}$ morju) opravljajo že $\mathrm{v}$ domačem kraju in ni potrebna uporaba avtomobila, poleg tega pa vsaj del tovrstnega prometa poteka po cestah in ulicah, na katerih ga omrežje števnih mest ne zazna. 
Skupen vpliv razpoložljivosti prostega časa in vremena na obseg cestnega prometa, ki je bil ugotovljen na primeru Koprskega primorja, je predvsem odraz turistične funkcije območja, saj je vpliv obeh dejavnikov na neprostočasni promet bistveno šibkejši in ga podatki za neturistična območja večinoma niso pokazali. V veliki meri je torej mogoče govoriti o specifičnih značilnostih turističnih območij oziroma tamkajšnjega prometa. V obravnavanem primeru ne gre zgolj za ciljno turistično območje, ampak tudi za prostor tranzitnih turističnih tokov in hkrati tudi za izvorno območje prostočasnih in turističnih prometnih tokov ter vsakodnevnega bivanja in gospodarskega delovanja lokalnega prebivalstva. Vsi ti vplivi se prepletajo in kažejo na ugotovljenih značilnostih prometa, ki pa vendarle razločno opozarjajo na ključno vlogo turizma na območju Koprskega primorja.

\section{Viri in literatura}

Anketa o tujih turistih v Republiki Sloveniji. Tuji turisti po prevoznem sredstvu, Slovenija, 2009. Statistični urad RS. URL: http://www.stat.si/doc/vsebina/turizem/Tuji\%20 turisti\%20po\%20PREVOZNEM\%20SREDSTVU,\%20Slovenija,\%202009.xls (Citirano 28. 8. 2013).

Brandenburg, C., Arnberger, A., 2001. The influence of weather upon recreation activities. V: Proceedings of the first international workshop on climate, tourism and recreation, str. 123-132. URL: http://www.mif.uni-freiburg.de/isb/ws/papers/full_report.pdf (Citirano 21. 5. 2013).

Campodónico, R., da Cunha, N., 2010. La incidencia del transporte en el desarrollo del turístico del Uruguay. El caso de ONDA (1935-1980). Estudios y perspectivas en turismo, 19, 3, str. 422-440. URL: http://www.scielo.org.ar/scielo.php?pid=S1851-173220 $10000300007 \&$ script $=$ sci_arttext (Citirano 28. 8. 2013).

Cigale, D., 2007. Tourism related transport in the Slovene Alps. Geografski radovi: naučni časopis za geografiju, 2, str. 91-102.

Environmental signals 2001. 2001. Luxembourg, Office for official publications of the European Communities, 113 str. URL: http://www.eea.europa.eu/publications/signals-2001/signals2001 (Citirano 28. 8. 2013).

Gómez Martín, M. B., 2005. Weather, climate and tourism: a geographical perspective. Annals of tourism research, 32, 3, str. 571-591. URL: http://www.glerl.noaa.gov/seagrant/ClimateChangeWhiteboard/Resources/Mac2/weather\%20climate\%20sceince. pdf (Citirano 28. 8. 2013).

Gössling, S., 2002. Global environmental consequences of tourism. Global environmental change, 12, 4, str. 283-302.

Hall, D. R., 1999. Conceptualising tourism transport: inequality and externality issues. Journal of transport geography, 7, 3, str. 181-188.

Hallo, J. C., Manning, R. E., 2009. Transportation and recreation: a case study of visitors driving for pleasure at Acadia National Park. Journal of transport geography, 17, str. 491-499. URL: http://www.uvm.edu/parkstudieslaboratory/publications/Hallo\%20 and\%20Manning\%20Transport\%20Geography.pdf (Citirano 28. 8. 2013). 
How Europeans spend their time. Everyday life of women and men. Data 1998-2002. 2004. Luxembourg, Office for official publications of the European Communities, 132 str. URL: http://epp.eurostat.ec.europa.eu/cache/ITY_OFFPUB/KS-58-04-998/ EN/KS-58-04-998-EN.PDF (Citirano 28. 8. 2013).

Jokić, N., Arnež, M., 2011. Turistična potovanja domačega prebivalstva, Slovenija, 2010 - končni podatki. Statistične informacije, 9/2011. Ljubljana, Statistični urad RS, 44 str. URL: http://www.stat.si/doc/statinf/21-si-082-1101.pdf (Citirano 17. 9. 2013).

Khadaroo, J., Seetanah, B., 2007. Transport infrastructure and tourism development. Annals of tourism research, 34, 4, str. 1021-1032.

Klimatski podatki - Portorož. Agencija RS za okolje. URL: http://www.arso.gov.si/vreme/napovedi\%20in\%20podatki/portoroz.html (Citirano 17. 9. 2013).

Lampič, B., Repe, B., 2009. Tipizacija prostora glede na prometno obremenjenost cest. V: Okoljski učinki prometa in turizma v Sloveniji (GeograFF 5). Ljubljana, Znanstvena založba Filozofske fakultete, str. 46-53.

Meteorološki letopis 2009. Ljubljana, ARSO, 2012. http:/www.arso.gov.si/vreme/ podnebje/meteorolo\%c5\%a1ki\%20letopis/meteoroloski_letopisi.htm (Citirano 28. 5. 2013).

Nastanitvena statistika po občinah - stara metodologija. 2012. Statistični urad RS. URL: http://pxweb.stat.si/pxweb/Database/Ekonomsko/21_gostinstvo_turizem/90_nastanitev_arhiv/01_21181_nastanitev_obcine_stara/01_21181_nastanitev_obcine_stara. asp (Citirano 21. 8. 2013).

Nastanitvena statistika, letni podatki - vsi objekti. 2012. Statistični urad RS. URL: http:// pxweb.stat.si/pxweb/Database/Ekonomsko/21_gostinstvo_turizem/02_21645_nastanitev_letno/02_21645_nastanitev_letno.asp (Citirano 21.8.2013).

Nastanitvena statistika, mesečni podatki - objekti z najmanj 10 stalnimi ležišči. 2012. Statistični urad RS. URL: http://pxweb.stat.si/pxweb/Database/Ekonomsko/21_gostinstvo_turizem/01_21644_nastanitev_mesecno/01_21644_nastanitev_mesecno.asp (Citirano 21. 8. 2013).

Nikolopoulou, M., 2001. The effect of climate on the use of open spaces in the urban environment: relation to tourism. V: Proceedings of the first international workshop on climate, tourism and recreation. URL: http://www.mif.uni-freiburg.de/isb/ws/papers/ full_report.pdf (Citirano 21. 5. 2013).

Ogrin, D., 1996. Podnebni tipi v Sloveniji. Geografski vestnik, 68, str. 39-56.

Ogrin, M., 2008. Prometno onesnaževanje ozračja z dušikovim dioksidom v Ljubljani (GeograFF 1). Ljubljana, Znanstvena založba Filozofske fakultete, Oddelek za geografijo, $87 \mathrm{str}$.

Ogrin, M., 2009. Prometno obremenjevanje ozračja. V: Okoljski učinki prometa in turizma v Sloveniji (GeograFF 5). Ljubljana, Znanstvena založba Filozofske fakultete, str. 62-72.

Ogrin, M., 2011. Je trajnosten razvoj zavarovanih območij mogoč brez trajnostne mobilnosti? V: Nared, J., Perko, D., Razpotnik Visković, N. (ur.). Razvoj zavarovanih območij v Sloveniji. Ljubljana, Založba ZRC, str. 127-137. 
Peeters, P., Szimba, E., Duijnisveld, M., 2007. Major environmental impacts of European tourist transport. Journal of transport geography, 15, 2, str. 83-93.

Prideaux, B., 2000. The role of the transport system in destination development. Tourism management, 21, 1, str. 53-63.

Promet 2009 - Podatki o štetju prometa na državnih cestah v Republiki Sloveniji. Ljubljana, Ministrstvo za promet, Direkcija Republike Slovenije za ceste, 2010.

Regnerus, H. D., Beunen, R., Jaarsma, C. F., 2007. Recreational traffic management: the relations between research and implementation. Transport policy, 14, 3, str. 258-267.

Špes, M., 2009. Promet in turizem na čereh pokrajinske občutljivosti Slovenije. V: Okoljski učinki prometa in turizma v Sloveniji (GeograFF 5). Ljubljana, Znanstvena založba Filozofske fakultete, str. 9-21.

Statistički ljetopis Republike Hrvatske 2010. URL: http://www.dzs.hr/Hrv_Eng/ljetopis/2010/SLJH2010.pdf (Citirano 21. 8. 2013).

Thompson, K., Schofield, P., 2007. An investigation of the relationship between public transport performance and destination satisfaction. Journal of transport geography, 15, 2, str. 136-144.

Vintar Mally, K., 2009. Zaznavanje prometa kot pritiska na okolje na izbranih območjih Slovenije. V: Okoljski učinki prometa in turizma v Sloveniji (GeograFF 5). Ljubljana, Znanstvena založba Filozofske fakultete, str. 73-85.

Vrtačnik Garbas, K., 2006. Povezanost med vremenom in obiskom izbranih turističnih točk v Sloveniji. Dela, 26, str. 133-160.

\section{INFLUENCE OF TOURISM ON THE CHARACTERISTICS OF ROAD TRAFFIC IN KOPRSKO PRIMORJE}

\section{Summary}

Tourism is necessarily closely related to transport. It influences also traffic volumes. The intensity of traffic, related to tourism, depends on number of tourists and transport modes. Consequently, differences between various areas and roads are very pronounced. In some places, the role of tourism-related traffic is almost negligible while in other places it is of the utmost importance. This is especially true for some most visited tourist areas. The characteristics of traffic in such areas differ from those in the areas without tourism or with only little tourism. These differences can be observed in weekly and seasonal variations of traffic. Other characteristic of traffic in such areas is its association with weather.

In the paper, tourism related characteristics of traffic in Koprsko primorje (Koper Littoral) have been studied. The Koprsko primorje area is - in regard to number of tourists - the most important Slovenian tourist area. In 2011, the three municipalities of Koprsko primorje (Koper, Izola, Piran), on only $1.9 \%$ of the state territory, contributed $18.7 \%$ of all tourist arrivals and $22.4 \%$ of all tourist bed-nights in Slovenia. Such popularity (number of tourists) also influences the increased road traffic. Consequently, this area is one of 
the areas with the highest numbers of vehicles in Slovenia. E.g., on the road Bertoki-Koper (Škocjan) the average daily number of vehicles in 2009 was 52,505. Larger numbers were registered only on some roads in the Ljubljana area.

In this research, for the analysis of traffic flows, data on daily number of vehicles in 2009 for all road traffic count points in the studied area (territory of municipalities Koper, Izola and Piran) were used. These data are regularly collected by the Slovenian Roads Agency.

Data on daily numbers of vehicles have been aggregated in regard to various time periods (summer tourist season/low season, weekends/working days) and daily values of weather parameters (temperature, cloudiness, amount of precipitation). The results were different average daily numbers of vehicles for each category. To analyze the relation between road traffic and weather characteristics, data of Environmental Agency of Slovenia for the weather station Portorož Airport have been used.

Traffic flows in the studied area are influenced by tourism to a large extent. The result of this are different characteristics of traffic (in regard to changes in traffic volume as a function of availability of free time and weather conditions) comparing to non-tourist areas. Nonetheless, this influence is not big enough to prevail completely over influences of local population and other economic activities. Therefore, even in the most important Slovenian tourist area, the consequence of the presence of numerous local population are - on some roads - similar to traffic characteristics of some non-tourist areas. Thus, on these roads the influence of tourism is less important than the influence of local population.

In the yearly average, the ratio of local population to the average daily number of tourists is about $15: 1$ (in 2011). Number of local population is thus much bigger than number of tourists. From this we can conclude that influence of tourism on road traffic is rather modest. Such a conclusion would be premature, since daily visitors and transit tourists (travelling to neighboring Croatia) should also be taken into account. From this viewpoint, analysis of data on road traffic (number of vehicles) better shows some characteristics of tourism (importance of daily visits, changes in visitor numbers within single months) than data of Statistical Office of the Republic of Slovenia, which take into account only tourist bed-nights and are available only for whole months and years. Therefore, study of traffic in tourist areas is inadequate if the role of local population, which contributes also to the traffic-related problems, is not taken into account.

Although it has not been explicitly mentioned, traffic characteristics are influenced also by leisure/recreational needs of the local population. In this case, similar time distribution of traffic (maximums on weekends, in summer, on days with nice weather) can be expected as in leisure-related traffic in general. This kind of influence of the local population can be discerned from the data on road traffic only partially - numerous leisure needs (e.g. swimming in the sea) can be satisfied in the home town and consequently the use of own car is not necessary. Nevertheless, at least part of this kind of traffic takes place on roads and streets without traffic count points.

The influence of free time availability and weather on traffic volumes, which has been found in Koprsko primorje, is the result of tourist function of the area. Their influence on non-leisure-related traffic is much more modest. Actually, on non-tourist areas it has 
not been shown. Thus, to a large extent, it is possible to consider traffic characteristics, related to changeability of weather and free time, as being specific for tourist areas. For Koprsko primorje, the studied area is not just tourist area but also transit space (transit tourist flows) and, at the same time, the place of origin of leisure and tourist traffic flows and everyday living and economic activities of local population. All these influences intertwine and are reflected in various traffic characteristics, which nonetheless clearly show the crucial role of tourism in the Koprsko primorje area.

(Translated by the author) 
